\title{
Reduced Transcutaneous Oxygen Tension and Impaired Vascular Response in Type 1 (Insulin-Dependent) Diabetes
}

\author{
R. Railton ${ }^{1}$, P. Newman ${ }^{1}$, J. Hislop ${ }^{2}$ and A. D. B. Harrower ${ }^{2}$ \\ ${ }^{1}$ Medical Physics Department, Monklands District General Hospital, Airdrie and West of Scotland Health Boards, Department of Clinical Phy- \\ sics and Bio-Engineering, Glasgow, and ${ }^{2}$ Medical Unit, Monklands District General Hospital, Airdrie, Scotland, UK
}

\begin{abstract}
Summary. Measurements of transcutaneous oxygen tension were made on the foot and arm in 16 Type 1 (insulin-dependent) diabetic patients with no evidence of vascular or neurological disease on simple clinical examination and in 30 nondiabetic subjects. The mean transcutaneous oxygen tension measured at $45^{\circ} \mathrm{C}$ on the foot was significantly lower in the diabetic patients than in the non-diabetic subjects. The hyperaemic response in the arm after cuff occlusion (measured by transcutaneous oxygen tension at $37^{\circ} \mathrm{C}$ ) was also significantly
\end{abstract}

lower in the diabetic patients. These results may reflect abnormal capillary blood flow in diabetic patients. As the methods are simple and non-invasive, they may prove useful in the early assessment and subsequent monitoring of peripheral vascular problems in diabetes.

Key words: Transcutaneous oxygen tension, vascular response, Type 1 diabetes, capillary blood flow.
The technique of transcutaneous oxygen tension $\left(\mathrm{TcPO}_{2}\right)$ measurement can provide a non-invasive method of estimating both arterial $\mathrm{PO}_{2}$ and tissue perfusion [1]. If the vascular bed is maximally dilated by heating to $45^{\circ} \mathrm{C}$ and adequately perfused, there is a good correlation between $\mathrm{TcPO}_{2}$ values and arterial $\mathrm{PO}_{2}$ in healthy adults [2]. With the electrode operating at a lower temperature (usually $37^{\circ} \mathrm{C}$ ), the $\mathrm{TcPO}_{2}$ reading is then related to skin perfusion and the technique can be used to assess reactive hyperaemia in the skin [3].

We have reported previously a reduction in $\mathrm{TcPO}_{2}$ values at $45^{\circ} \mathrm{C}$ in patients with peripheral vascular disease [4], but whether such abnormalities in $\mathrm{TcPO}_{2}$ can be detected in diabetic patients with no clinical evidence of vascular disease is unknown. Reduction in vascular reactivity in diabetic children has been reported [5] and we have, therefore, investigated a group of adult Type 1 (insulin-dependent) diabetic patients to determine whether there are any differences in $\mathrm{TcPO}_{2}$ or in vascular reactivity compared with normal subjects.

\section{Patients and Methods}

Sixteen Type 1 diabetic patients, eight females and eight males, mean \pm SD age $28 \pm 6$ years (range $18-39$ years) were studied (Table 1 ). None had any symptoms of leg pain or claudication and all had palpable lower limp pulses including dorsalis pedis and posterior tibial pulses. Lower limb reflexes, pin prick and touch sensation and ankle vibration sense using a tuning fork $(128 \mathrm{~Hz})$ were also normal in all patients. Thirty normal subjects ( 11 females and 19 males) aged from 20 to 63 years were also studied. Twenty-two of this group ( 11 females and 11 males) were aged $<40$ years (mean \pm SD: $28.4 \pm 6.1$ years) and were used as control subjects. All gave informed consent. Six of the diabetic patients and 11 of the control subjects were regular smokers of $20-40$ cigarettes daily. All subjects refrained from smoking for a minimum of $1 \mathrm{~h}$ before the procedure and were studied supine. The left arm and left foot were exposed and clothing loosened around the arm and leg to prevent any obstruction to blood flow. The examination room was maintained close to $26^{\circ} \mathrm{C}$ to prevent vasoconstriction. Measurements of $\mathrm{TcPO}_{2}$ were made on the left arm and left foot simultaneously using a twin channel Oxymeter (Draeger Medical, Hemel Hempstead, UK) and chart recorder. In this system, the sensor electrode is attached to the skin by a self-adhesive ring. Before each measurement, the zero level was checked using the manufacturer's zero solution (sodium dithionite) and the system calibrated in air. One of the sensors, set to operate at a temperature of $37^{\circ} \mathrm{C}$, was attached to the flexor aspect of the left forearm, approximately midway between the wrist and elbow. The other sensor (set to a temperature of $45^{\circ} \mathrm{C}$ ) was attached to the dorsum of the left foot. Care was taken to avoid skin blemishes, superficial veins, scar tissue and hair. In both situations, the cable was taped to the skin to minimize strain at the electrode site. The chart recorder was started once the electrodes were in place.

After a stabilisation period of at least $15 \mathrm{~min}$ (or until the indicated forearm reading was steady), a cuff was placed around the left arm and inflated to a pressure of $50 \mathrm{mmHg}$ above systolic. This pressure was maintained for $4 \mathrm{~min}$; the hyperaemic response upon removing the cuff was monitored for a minimum of $15 \mathrm{~min}$, or until equilibrium was re-established. The cuff was again placed around the left arm and the procedure repeated.

Finally, the sensors were removed, the calibration checked in air and the recorder stopped. The skin temperature close to the electrode 


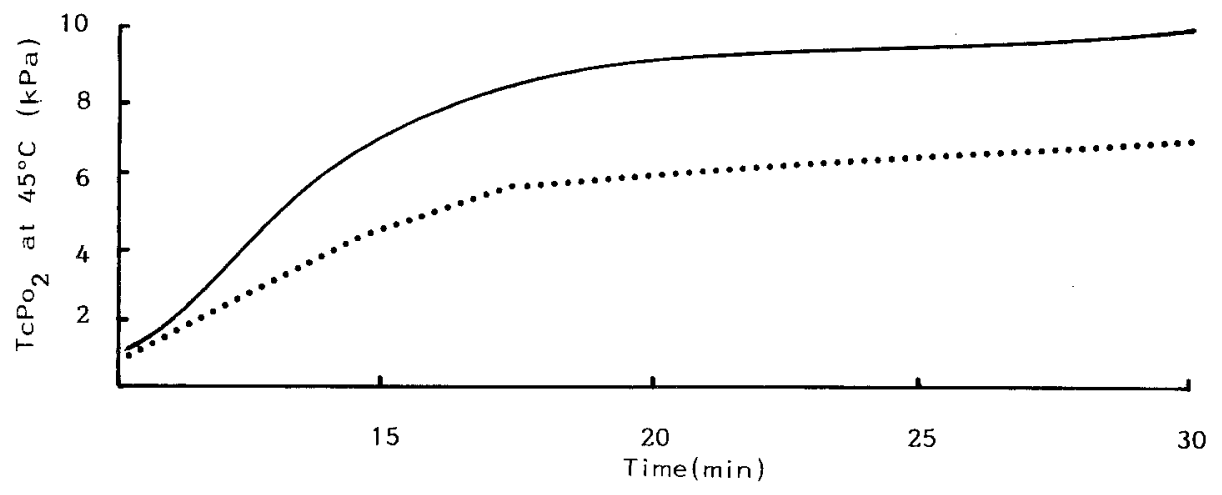

Fig. 1. Foot $\mathrm{TcPO}_{2}\left(45^{\circ} \mathrm{C}\right)$ versus time for a normal subject (solid line) and a diabetic subject (dotted line)

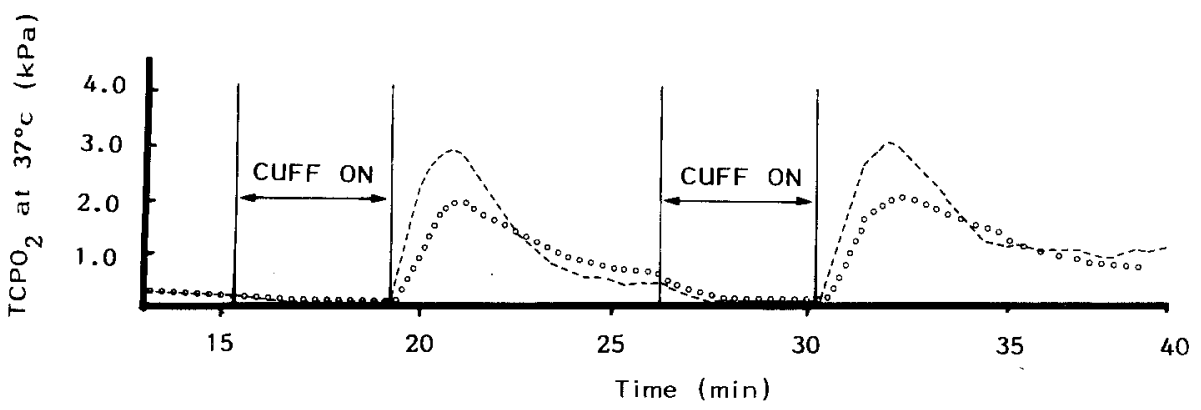

Fig. 2. Hyperaemic responses of a normal subject (dashes) and a diabetic subject (circles). $\mathrm{TcPO}_{2}$ was measured at $37^{\circ} \mathrm{C}$ on the forearm

Table 1. Characteristics of the patients studied

\begin{tabular}{|c|c|c|c|c|c|c|}
\hline Patient & $\begin{array}{l}\text { Age } \\
\text { (years) }\end{array}$ & Sex & $\begin{array}{l}\text { Duration } \\
\text { of } \\
\text { diabetes } \\
\text { (years) }\end{array}$ & $\begin{array}{l}\text { History } \\
\text { of } \\
\text { cigarette } \\
\text { smoking }\end{array}$ & $\begin{array}{l}\text { Plasma } \\
\text { glucose } \\
(\mathrm{mmol} / \mathrm{l})\end{array}$ & $\begin{array}{l}\mathrm{HbA}_{1} \\
(\%)\end{array}$ \\
\hline 1 & 20 & $\mathrm{M}$ & 3.5 & - & 3.4 & 6.8 \\
\hline 2 & 25 & $\mathrm{~F}$ & 1.5 & - & 11.7 & 8.3 \\
\hline 3 & 22 & $\mathbf{F}$ & 13 & + & 4.2 & 10.6 \\
\hline 4 & 33 & $\mathbf{M}$ & 2.5 & $t$ & 11.0 & 6.6 \\
\hline 5 & 31 & $\mathbf{M}$ & 19 & - & 17.4 & 10.0 \\
\hline 6 & 30 & $\mathrm{~F}$ & 5 & + & 9.8 & 7.4 \\
\hline 7 & 39 & F & 1 & + & 11.4 & 8.3 \\
\hline 8 & 22 & F & 9 & - & 10.7 & 6.6 \\
\hline 9 & 28 & $F$ & 3 & - & 6.6 & 8.7 \\
\hline 10 & 22 & M & 3 & - & 6.6 & 8.7 \\
\hline 11 & 35 & $F$ & 7 & - & 5.5 & 7.9 \\
\hline 12 & 30 & M & 4 & - & 8.6 & 7.4 \\
\hline 13 & 34 & $\mathrm{~F}$ & 1.6 & - & 2.9 & 8.2 \\
\hline 14 & 33 & M & 7 & + & 12.9 & 10.1 \\
\hline 15 & 29 & $\mathrm{M}$ & 12 & + & 5.7 & 8.6 \\
\hline 16 & 18 & M & 7 & - & 13.8 & 9.6 \\
\hline $\begin{array}{l}\text { Mean } \pm \\
\text { SD }\end{array}$ & $28.2 \pm 6.1$ & - & $6.2 \pm 5.0$ & - & $8.9 \pm 4.1$ & $8.4 \pm 1.2$ \\
\hline
\end{tabular}

site (but avoiding the reddened areas of skin) was measured using a Fluke 80T-150 thermistor probe (Fluke BV, Tilburg, The Netherlands) and, in the diabetic patients, blood samples were obtained.

The following parameters were measured from each recording:(1) foot $\mathrm{TcPO}_{2}$ after 15 min stabilisation; (2) arm $\mathrm{TcPO}_{2}$ values preceding occlusion; (3) changes in arm $\mathrm{TcPO}_{2}$ post-occlusion (peak value preceding value)

Plasma glucose levels were measured by a Beckman autoanalyser and glycosylated haemoglobin $\left(\mathrm{HbA}_{1}\right)$ concentrations by an electrophoretic method using a commercially available kit (Corning, Halstead, Essex, UK). The normal range for our laboratory is $5.6 \%-8.7 \%$.
Statistical analyses were carried out using the Wilcoxon rank tests for two samples or pair differences, and the Spearman rank test for correlations.

\section{Results}

\section{Foot $\mathrm{TcPO}_{2}$}

Typical recordings for a control subject and a diabetic patient are shown in Figure 1. The $\mathrm{TcPO}_{2}$ value was taken as the average over the last $10 \mathrm{~min}$ of the recording. The mean $\mathrm{TcPO}_{2}$ for the diabetic group was $7.9 \pm$ $1.7 \mathrm{kPa}$ which was significantly lower than the mean value of $9.5 \pm 1.1 \mathrm{kPa}$ for the control group $(p<0.01)$. One diabetic patient had a fluctuating value which has been excluded from the mean.

The mean $\mathrm{TcPO}_{2}$ for normal subjects aged between 53 and 63 years $(n=8)$ was $7.3 \pm 2.2 \mathrm{kPa}$ and a negative correlation with age was found for the non-diabetic group ( $r=0.41, p<0.05$ ). No correlation with age was found for the diabetic patients or the young control subjects. The sex dependence of this parameter was tested in the control group. The 11 female subjects were found to have a mean $\mathrm{TcPO}_{2}$ of $9.5 \pm 1.0 \mathrm{kPa}$ compared with $9.4 \pm 1.1 \mathrm{kPa}$ for the 11 male subjects, which was not significantly different.

\section{$\mathrm{Arm} \mathrm{TcPO}_{2}$}

Typical arm recordings for a control subject and a diabetic patient are shown in Figure 2. The mean (steady) $\mathrm{TcPO}_{2}$ in the diabetic patients before occlusion was 
$0.37 \pm 0.46 \mathrm{kPa}$ and in the 22 control subjects $0.17 \pm$ $0.21 \mathrm{kPa}$ but the difference was not significant. During occlusion, $\mathrm{TcPO}_{2}$ fell to zero in all subjects. The mean post-ischaemic change (peak value - preceding steady value) in $\mathrm{TcPO}_{2}$ in the diabetic patients was $2.0 \pm 1.0$ $\mathrm{kPa}$ which was significantly lower than in the control group, $2.9 \pm 1.2 \mathrm{kPa}(p<0.05)$.

After the first occlusion, $\mathrm{TcPO}_{2}$ stabilized at $0.52 \pm$ $0.51 \mathrm{kPa}$ in the diabetic patients, which was not significantly different from the $\mathrm{TcPO}_{2}$ before occlusion. In the control group, $\mathrm{TcPO}_{2}$ was significantly higher after occlusion $(0.54 \pm 0.48 \mathrm{kPa})$ than the $\mathrm{TcPO}_{2}$ before occlusion $(p \ll 0.01)$.

The mean post-ischaemic change in $\mathrm{TcPO}_{2}$ after the second occlusion was $2.1 \pm 1.0 \mathrm{kPa}$ in the diabetic patients and $2.2 \pm 1.0 \mathrm{kPa}$ in the control subjects (NS). The difference of $0.7 \pm 1.2 \mathrm{kPa}$ between the first and second post-ischaemic changes in the control subjects was significant $(p<0.05)$ but no significant difference was found in the diabetic patients.

In all the normal subjects, a negative correlation was found between the post-ischaemic change in $\mathrm{TcPO}_{2}$ and age $(r=-0.54, p<0.01)$, but there was no such correlation in the control subjects alone. There was, however, a significant negative correlation with age in the diabetic patients $(r=-0.61, p<0.02)$.

The mean arm temperature in the diabetic group was $33.0 \pm 1.0^{\circ} \mathrm{C}$ compared with $32.8 \pm 0.8^{\circ} \mathrm{C}$ in the control group. The mean foot temperature in the diabetic group was $32.2 \pm 1.2^{\circ} \mathrm{C}$ compared with $32.9 \pm 1.3^{\circ} \mathrm{C}$ in the control group. None of these values was significantly different. The foot temperature $\left(28.5^{\circ} \mathrm{C}\right)$ of the diabetic patient who showed a fluctuating $\mathrm{TcPO}_{2}$ value has been excluded.

No correlation was found between the skin temperature and either the foot $\mathrm{TcPO}_{2}$ or the post-ischaemic changes in the arm in any of the groups.

No correlation could be found between either foot $\mathrm{TcPO}_{2}$ or post-ischaemic change in arm and plasma glucose or $\mathrm{HbA}_{1}$ concentrations.

\section{Discussion}

The $\mathrm{TcPO}_{2}$ in the foot and after ischaemic occlusion in the arm was lower in diabetic patients compared with control subjects. The abnormal hyperaemic response is similar if less marked than that reported by Ewald et al. in diabetic children [5]. There was also an age-related fall in the post-ischaemic change in $\mathrm{TcPO}_{2}$ in the diabetic patients which was not found in the control subjects, although there was a similar trend in the normal group as a whole.

Abnormalities of blood flow [6] and venous oxygenation [7] have been reported in the foot with diabetic neuropathy and arteriovenous shunting [8] could partly explain these findings. While our patients had no clinical evidence of significant peripheral vascular disease or neuropathy, early changes in blood flow or nerve conduction could still be present. This might produce both abnormal capillary flow at rest and abnormal changes in capillary flow after ischaemic occlusion. Such changes could partly explain the fluctuating foot $\mathrm{TcPO}_{2}$ value in one patient. Similar studies of patients with objective evidence of varying degrees of blood flow and neuropathic abnormalities are required to determine the effect, if any, on $\mathrm{TcPO}_{2}$.

It is interesting that, in the normal subjects, the baseline $\mathrm{TcPO}_{2}$ following the first hyperaemic response was significantly higher than the initial baseline value. Whether the period of hypoxia temporarily altered capillary flow is difficult to say, but the result was to produce a baseline $\mathrm{TcPO}_{2}$ very similar to that in the diabetic patients.

As abnormalities in nerve conduction, for example, are reversed by improved blood glucose control [9], it is important to assess the effect of diabetic control on $\mathrm{TcPO}_{2}$ by further studies. The methods described are simple to use, non-invasive and may be repeated safely. They may prove useful in the assessment of the peripheral circulation in diabetic patients.

Acknowledgements. The equipment described in this paper was provided by a grant from the Scottish Home and Health Department. We are grateful to Mr. G. A. Gilmour for carrying out the glycosylated haemoglobin assays.

\section{References}

1. Huch A, Huch R, Arner B, Rooth G (1973) Continuous transcutaneous oxygen tension measured with a heated electrode. Scan J Clin Lab Invest 31: 269-275

2. Huch A, Huch R, Hollman G, Hockerts T, Keller HP, Seiler D, Sadzek J, Lubbers DW (1977) Transcutaneous $\mathrm{PO}_{2}$ of volunteers during hyperbaric oxygenation. Biotelemetry $4: 88-100$

3. Ewald U, Rooth G, Tuvemo T (1981) Post-ischaemic hyperaemia studied with a transcutaneous oxygen electrode used at $33-37^{\circ} \mathrm{C}$. Scand J Clin Lab Invest 41: 641-645

4. Young KC, Railton R, Harrower ADB, Brookers RW (1981) Transcutaneous oxygen tension measurements as a method of assessing peripheral vascular disease. Clin Phys Physiol Meas 2: 145-151

5. Ewald U, Tuvemo T, Rooth G (1981) Early reduction of vascular reactivity in diabetic children detected by transcutaneous oxygen electrode. Lancet 1: 1287-1288

6. Edmunds ME, Roberts VC, Watkins PJ (1982) Blood flow in the diabetic neuropathic foot. Diabetologia 22:9-15

7. Boulton AJM, Scarpello JHB, Ward JD (1982) Venous oxygenation in the diabetic neuropathic foot. Diabetologia 22: 6-8

8. Ward JD (1982) The diabetic leg. Diabetologia 22: 141-147

9. Ward JD, Barnes CG, Fisher DJ, Jessop JD, Bates RWR (1971) Improvement in nerve conduction following treatment in newly diagnosed diabetics. Lancet $1: 428-431$

Received: 7 October 1982

and in revised form: 21 July 1983

Dr. R. Railton

Medical Physics Department

Monklands District General Hospital

Monkscourt Avenue

Airdrie ML6 OJS

Scotland 